\title{
Weg van geluid: hoe de auto een plaats werd om tot rust te komen
}

Citation for published version (APA):

Bijsterveld, K. T. (2007). Weg van geluid: hoe de auto een plaats werd om tot rust te komen. Universiteit Maastricht. https://doi.org/10.26481/spe.20071207kb

Document status and date:

Published: 07/12/2007

DOI:

10.26481/spe.20071207kb

Document Version:

Publisher's PDF, also known as Version of record

\section{Please check the document version of this publication:}

- A submitted manuscript is the version of the article upon submission and before peer-review. There can be important differences between the submitted version and the official published version of record.

People interested in the research are advised to contact the author for the final version of the publication, or visit the DOI to the publisher's website.

- The final author version and the galley proof are versions of the publication after peer review.

- The final published version features the final layout of the paper including the volume, issue and page numbers.

Link to publication

\footnotetext{
General rights rights.

- You may freely distribute the URL identifying the publication in the public portal. please follow below link for the End User Agreement:

www.umlib.nl/taverne-license

Take down policy

If you believe that this document breaches copyright please contact us at:

repository@maastrichtuniversity.nl

providing details and we will investigate your claim.
}

Copyright and moral rights for the publications made accessible in the public portal are retained by the authors and/or other copyright owners and it is a condition of accessing publications that users recognise and abide by the legal requirements associated with these

- Users may download and print one copy of any publication from the public portal for the purpose of private study or research.

- You may not further distribute the material or use it for any profit-making activity or commercial gain

If the publication is distributed under the terms of Article $25 \mathrm{fa}$ of the Dutch Copyright Act, indicated by the "Taverne" license above, 


\section{Weg van geluid}

Hoe de auto een plaats werd om tot rust te komen 


\section{Colofon}

Ontwerp en print: Océ Business Services, Maastricht

Illustratie op omslag: detail van reclamemateriaal voor Philips autoradio (1953),

met dank aan Philips Company Archives.

ISBN: 978-90-5681-274-4

NUR: 740

Alle rechten voorbehouden. Niets uit deze uitgave mag worden verveelvoudigd, opgeslagen in een geautomatiseerd gegevensbestand of openbaar gemaakt worden, zonder voorafgaande schriftelijke toestemming van de auteur of uitgever. 


\section{Weg van geluid}

Hoe de auto een plaats werd om tot rust te komen

\section{Rede}

Uitgesproken bij de aanvaarding van het ambt van bijzonder hoogleraar Wetenschap, Technologie en Moderne Cultuur aan de Faculteit Cultuur-en Maatschappijwetenschappen van de Universiteit Maastricht

op vrijdag 7 december 2007

door

dr. Karin Bijsterveld 

Mijnheer de Rector, geachte collega's, dames en heren

\section{Inleiding}

We kijken naar een reclamefilm en zien een man van middelbare leeftijd, type universitair docent. Hij werkt in een bibliotheek. Het wil niet erg vlotten. De geluiden van de andere aanwezigen leiden hem af. Een jonge vrouw laat haar pen nerveus in haar hand tikken. Een blondine verfrommelt een vel papier. Er rinkelt een mobiele telefoon. Met een afwezige blik brengt een mollige man chips naar zijn mond - het kraakt. Zelfs het ritmische geluid van een walkman dreunt door. De universitair docent geeft het op. Hij ontvlucht de bibliotheek, regelrecht zijn auto in. Nog even horen we de geluiden van de stad. Dan klapt de man het portier dicht en ontspant. Eindelijk: rust. En terwijl de auto, een Toyota Avensis, over het wegdek glijdt, verschijnt een tekst in beeld: "Zelfs de stilte is standaard". Bij deze auto krijgt u niet alleen de airconditioning zonder extra kosten bijgeleverd, maar ook de stilte.'

Het filmpje dateert van 1999 en staat niet op zichzelf. Ook MercedesBenz en Volkswagen lieten in de jaren negentig via reclamefilms weten dat hun wagens de rust konden bieden die daarbuiten ontbrak. ${ }^{2}$ En in dagblad- en tijdschriftadvertenties is het geluid van de auto tegenwoordig opvallend aanwezig. De Chrysler Voyager heeft, aldus de fabrikant, een "ruim", "comfortabel" én "fluisterstil" interieur. ${ }^{3}$ In de Ford Focus maakt "Alles wat u aanraakt... het geluid dat het hoort te maken." Een Jaguar S-type wordt aangedreven door een "Stille kracht", maar de motoren van de Honda Accord zijn "misschien wel de stilste in hun klasse". "Een mens krijgt 469.082 geluidsprikkels per minuut", schrijft BMW. “Het begint met de wekker. En het eindigt meestal met 'welterusten' (of een snurk). Daartussen draaien uw oren overuren. Af en toe rust is dan ook zeker op zijn plaats. Bijvoorbeeld in een diesel van BMW".7

Het lijkt ironisch dat de auto wordt voorgesteld als de plaats om tot rust te komen. Uit enquêtes blijkt dat Nederlanders juist het wegverkeer als de belangrijkste bron van geluidsoverlast beschouwen (De Jong et al. 2000: 66). ${ }^{8}$ De gedachte dat een auto meer rust biedt dan een bibliotheek spot helemáál met onze intuïties. In de $10^{\mathrm{e}}$ eeuw werd het hardop lezen geleidelijk vervangen door het in stilte lezen (Manguel 1999). Sindsdien worden bibliotheken geacht oorden van rust te zijn. Geleerden werden ver van lawaai gehouden. Tot de vroeg-moderne privileges van Leidse doctoren en professoren behoorden niet alleen de "vrijdom van belastingen", maar ook "de vrijdom van lawaai" (Otterspeer 2000: 297). Dat privilege werd in de $17^{\mathrm{e}}$ eeuw door de rechtenfaculteiten van Jena 
en Leipzig beschermd door smidsen te verbieden zich te vestigen in straten waar al een hoogleraar woonde (Wiethaup 1966: 121). De gedachte dat geleerden van nu zich gemakkelijker kunnen concentreren in een auto dan in een bibliotheek, spreekt dan ook boekdelen over het vertrouwen van autofabrikanten in de stilte op vier wielen. Daarbij maken reclamemakers handig gebruik van de eeuwenoude associatie van geleerdheid met rust. Zo meldt een advertentie voor de Chevrolet Epica Business Edition dat het "slimste jongetje van de klas ... opvallend vaak ook de stilste" is. ${ }^{9}$

Toch is de rust die de auto biedt meer dan alleen een gewiekst argument waarmee fabrikanten de auto aan de mens brengen. Voor velen is de auto tegenwoordig, zo menen vervoerspsychologen "een verlengstuk van de woonkamer: mensen komen er tot rust." Het is het enige moment op de dag waarop ze "alleen zijn: geen collega's om zich heen en niet de drukte van het gezin". "In dat licht," zo constateert het weekblad Intermediair, is de file "lang zo erg niet" als die lijkt. Het zou zelfs het failliet van het carpoolen kunnen verklaren. ${ }^{10}$ Voor wie de mobiele telefoon uitzet en zelf bepaalt wanneer hij belt, kan de auto het laatste bastion van privacy zijn. Dat bastion geven mensen niet graag op.

Het hoeft in de auto niet letterlijk stil te zijn, maar het is wel de plaats waar mensen hun akoestische omgeving denken te kunnen beheersen. Of iemand privacy ervaart, wordt volgens sociaal-psycholoog Irwin Altman niet zozeer bepaald door de mate van iemands isolement, als wel door de mate waarin iemand controle heeft over wie tot zijn domein toegang heeft (Altman 1976). Dat geldt ook voor de auditieve privacy in de auto. Zo heeft mediasocioloog Michael Bull laten zien hoe het luisteren naar de radio, cassettebandjes of cd's automobilisten het gevoel geeft hun reis in de hand te hebben. Zij maken van de hen opgedrongen files zelf ingevulde tijd, voorzien zich van virtueel gezelschap op verlaten wegen, en maken hun reis voorspelbaar door af te stemmen op steeds weer dezelfde programma's. Daarbij voelen ze zich in de auto vrijer dan thuis. Mensen gebruiken audioapparatuur ook in de huiselijke omgeving om zichzelf in een bepaalde stemming te brengen of herinneringen op te roepen (DeNora 2000). Maar automobilisten kunnen, mits alleen, hun muziek hard zetten, vals meezingen en hun eigen soundtrack creëren zonder anderen te storen of afgeluisterd te worden. Dat doen ze in een ruimte die hermetisch van de buitenwereld afgesloten lijkt en die de buitenwereld tot een soort film maakt, net niet helemaal echt. Zo beheersen automobilisten via geluidsapparatuur wie of wat toegang heeft tot hun persoonlijke ruimte (Bull 2003, 2004, Stockfelt 1994)." 
Het autorijden zelf heeft temidden van files, maximum snelheden, voorgeschreven routes en uitzicht beperkende geluidsschermen weinig meer te maken met het ideaal van vrijheid waarvoor de auto ooit stond (Urry 1999, 2000). Niet dat automobilisten zichzelf geen vrijheid toeschrijven. Wie van $u$ kiest niet de enig juiste baan in de file of vindt handig die allerbeste parkeerplaats (Oel 2005)? Je moet wát om het leven spannend te houden. Maar in de praktijk rollen we vaak in gestandaardiseerde "passages" van A naar B, zo heeft mijn collega Peter Peters (2006) terecht opgemerkt. In die situatie biedt de binnenruimte van de auto een keuzevrijheid en controle die buiten afneemt. In de auto voelen we ons veilig, hoe onterecht ook, en achten we onszelf heer en meester over de geluidsruimte. Nu we luisterboeken hebben, zo stelt columnist Ger Groot, is de auto een ware "akoestische bibliotheek" geworden (Groot 2005: 45).

Op het eerste gezicht lijken we de paradoxale positie van de autobron van geluidsoverlast en oord van rust-dus psychologisch te kunnen verklaren. Juist omdat we zo lawaaiig mobiel zijn, zo rusteloos bereikbaar en troosteloos ingesnoerd, is het apparaat waarmee we ons bewegen de plaats om tot rust te komen. Ons rijdend cocon kan geen kant op, maar erbinnen ervaren we controle en komen we tot onszelf. Het lijkt zo logisch. Maar dat is het alleen omdat we het inmiddels vanzelfsprekend vinden, dat het autogeluid zo gedempt is dat we in de auto kunnen beluisteren wat we willen. In de tijd terugkijkend zou je dan ook verwachten dat eerst de auto stil werd en toen de autoradio werd ingevoerd. Maar niets is minder waar. Het is buitengewoon vreemd dat we een apparaat dat door een explosiemotor wordt aangedreven-onze auto-tot luistercabine hebben gemaakt.

Daarmee kom ik op de vraag die ik me voor vanmiddag heb gesteld: Hoe heeft de auto zich tot akoestisch cocon ${ }^{12}$ kunnen ontwikkelen? Hoe kon de auto tot het domein worden waarin mensen privacy en ontspanning ervaren omdat zij het geluid ervan prettig en controleerbaar achten? Terwijl ik die vragen beantwoord, hoop ik $u$ tegelijkertijd te laten zien dat technologische vernieuwingen als de autoradio en geluiddempende materialen eerst naar bestaande gebruiken moeten buigen om werkelijk innovaties te kunnen worden. Om in autotermen te blijven: eerst invoegen, dan doorrijden-technologie moet kunnen "ritsen". Met die metafoor wil ik u in de sfeer van het autorijden houden en benadrukken dat het "ritsen" van technologie heel snel gaat: het zijn uiterst korte momenten. 
Juist omdat het van die korte momenten zijn, lijkt het alsof technologische vernieuwing uit de lucht komt vallen en het logisch is dat we nu auto's hebben waarin we naar onze favoriete muziek kunnen luisteren. Maar een bedrijf dat een nieuwe technologie wil laten ritsen, moet haarfijn op de hoogte zijn van de maatschappelijke gebruiken en culturele symboliek in de samenleving waarin de technologie moet worden ingevoegd. En wie die invoegprocessen historisch wil bestuderen, zoals ik, moet dus niet alleen verstand hebben van de wetenschap en technologie die in een nieuw apparaat zit ingebouwd, maar ook van moderne cultuur. Dan zal bovendien duidelijk worden dat wie een leerstoel bezet met de titel "Wetenschap, technologie en moderne cultuur" niet over alles gaat-helaas niet-maar over de mechanismen aan de hand waarvan wetenschap en technologie maatschappelijk en cultureel "ritsen". Daarom neem ik u mee naar drie invoegmomenten van de technologie van geluid in de auto: drie episodes in de ontwikkeling van de auto én van onze cultuur die de auto tot akoestisch cocon maakten.

\section{Een aardige radio-ontvangst-zolang de auto stil staat}

Al begin jaren twintig werden radio's in auto's meegenomen. Aanvankelijk waren dat draagbare reis- of kofferradio's met batterijen (Klawitter et al. 2005). Vanaf 1928 ging het echter ook om volledig in de auto ingebouwde exemplaren, zoals de Amerikaanse Transitone. ${ }^{13}$ In de jaren erna volgden ondermeer Motorola, Crosley en in Europa: Blaupunkt en Philips.

Aanvankelijk nam ik aan dat het moment waarop de radio in de auto werd geïntroduceerd samenhing met het moment waarop de auto een gesloten carrosserie kreeg. Dat gebeurde namelijk ook in de jaren twintig, terwijl auto's daarvoor, om ze licht te houden, open koetsen waren geweest (Merki 2002, Volti 2004). Zonder een gesloten carrosserie zou het geluid van de autoradio immers door omgevingsgeluid zijn overstemd, zo redeneerde ik. Maar daarmee ging ik te veel uit van het huidige gebruik van de autoradio, zo bleek toen ik het Philips archief indook. De vroege reclame voor de autoradio richtte zich namelijk niet uitsluitend op het luisteren naar de radio in een gesloten, rijdende auto, maar vooral op het luisteren naar de radio in een stilstaande, open auto en niet alleen door degenen die zich in, maar ook juist buiten de auto bevonden.

Waar het idee voor de autoradio precies vandaan kwam is nog onvoldoende onderzocht. Er zijn aanwijzingen dat Amerikaanse radio- 
amateurs al jaren voor de introductie van de Transitone met autoradio's experimenteerden. ${ }^{14} \mathrm{Om}$ dat te begrijpen moeten we iets meer weten over de positie van de radio in het dagelijks leven van Amerikanen op dat moment. In 1930 had in de Verenigde Staten al 40 procent van de huishoudens een radio. Nog weer tien jaar later was dit ruim 80 procent (Butsch 2000: 176, 205). In de jaren twintig was het bovendien gewoon geworden om het luisteren naar de radio met andere activiteiten te combineren (Douglas 1999: 84). Wie met de auto ging kamperen of picknicken, kon dus gemakkelijk op het idee komen een radio mee te nemen. ${ }^{15}$ En vermoedelijk zochten radiofabrikanten naar nieuwe afzetmarkten. Mobiele radio's werden namelijk niet alleen in personenauto's geïntroduceerd, maar ook in de wagens van politie en brandweer, in taxi's, bussen, treinen, vliegtuigen, op boten en zelfs op fietsen (Schiffer 1991: 113-115, Weber 2006: 168).

In de Verenigde Staten werd de autoradio redelijk snel populair, al waren de eerste jaren vanwege de economische crisis voor de fabrikanten niet gemakkelijk. Niettemin was in 194130 procent van alle auto's uitgerust met een autoradio en had de helft van de in dat jaar verkochte nieuwe auto's een autoradio (Butsch 2000: 206). In Europa verliep dit proces veel trager, maar daar werden in deze periode ook veel minder auto's verkocht dan in Amerika. In 1966 was nog slechts 17 procent van het totaal aantal Europese auto's met een autoradiotoestel uitgerust, al had vier jaar later al meer dan de helft van de Duitse auto's een radio (Weber 2006: 165).

De Amerikaanse autoradio werd in reclamemateriaal aanvankelijk vooral met romantiek geassocieerd. In de oudst bekende reclamefilm voor de Philips autoradio, uit 1952, gebeurde dat ook nog. De Philips radio werd in 1934 geïntroduceerd, maar het filmpje uit 1952 staat duidelijk nog in de romantische traditie. ${ }^{16}$ Hoewel we Nederlandse stemmen horen, is de film in een Amerikaanse setting opgenomen. We zien een straatmuzikant die prachtig lijkt te kunnen spelen. Al snel komen we er achter dat we niet de viool van de straatmuzikant horen, maar de radio van de open auto die vlak voor de violist geparkeerd staat. Wanneer de auto wegrijdt, wordt ook de straatmuzikant door een agent weggestuurd. De muzikant, zo is de boodschap, kan niet op tegen de hoge kwaliteit van het geluid van de Philips autoradio. Vervolgens zien we dat de auto met de radio door een bestuurder van een gesloten auto wordt ingehaald. Als die bestuurder bij een landhuis arriveert, toetert hij. Op het balkon verschijnt een vrouw, maar verder doet ze niets. Even later komt de automobilist met de open auto aan. Hij zet zijn autoradio 
wat harder. Dit maal zwaait de dame en-u begrijpt het al—stapt een oogwenk later in bij de man met de autoradio. Het filmpje heet dan ook The Secrets of his Power. ${ }^{17}$

Een aanzienlijk deel van het voor- en direct naoorlogse reclamemateriaal van Philips draagt precies dit uit: dat een autoradio, doorgaans afgebeeld in een open auto of een auto met een open portier, de aandacht trekt van een bewonderende vrouw of een bewonderend publiek. ${ }^{18}$ Ongetwijfeld dacht Philips daarmee aan te sluiten bij wat het bedrijf de preoccupaties achtte van de jonge mannen die vaak de early adopters zijn van nieuwe technologie (Smit \& van Oost 1999). ${ }^{19}$ Maar uit het archief van Philips valt af te leiden dat er nog meer aan de hand was. Philips had in die jaren in het buitenland correspondenten, een soort verklikkers die beurzen afstruinden, in de gaten hielden wat er aan nieuwe technologie op de markt kwam, en rapporteerden wat daarover in lokale kranten werd geschreven. De Philips correspondent in de Verenigde Staten, consulting engineer L.P. Graner, maakte in brieven vanaf 1929 melding van de eerste inbouw autoradio's. Die waren volgens hem duur en niet veel soeps. Met een koperen of aluminium antenne in het dak en een handige plaatsing van batterijen en luidspreker was de ontvangst in de auto heel aardig-zolang de auto stil stond. Maar werd er gereden, dan konden de versterkerbuizen van de radio kapot rammelen, maakte de motor meer lawaai dan de radio, en werd de radio-ontvangst ernstig gestoord door de elektromagnetische golven die vrijkwamen bij het ontstekingsproces in de bougies-een verschijnsel dat we interferentie noemen.

Maakte de benzineauto op dat moment dan nog zoveel lawaai? Absoluut! Omdat het principe van de interne verbrandingsmotor is gebaseerd op het beheerst laten ontploffen van een benzineluchtmengsel dat in een cilinder is samengeperst, knalde de benzinemotor erop los en deed de hele auto vibreren. De benzineauto maakte daardoor meer lawaai dan de auto's op stoom en elektriciteit die aan het eind van de negentiende eeuw ook nog rondreden (Volti 2004: 7). Maar voor het type man dat zich in die jaren met de benzineauto voortbewoog-rijke ingenieurs, artsen en zakenmensen-was dat lawaai geen probleem. Integendeel, lawaai stond voor kracht, en met herrie viel de omgeving te imponeren (McShane 1994: 169, Mom 1997: 475). Het lawaai van de benzineauto was alleen in bepaalde contexten een probleem. Zo duurde het in Amerika tot in de jaren dertig van de $20^{\mathrm{e}}$ eeuw voordat het aanvaardbaar werd geacht om de auto voor begrafenissen te gebruiken (Berger 1979: 183). Pas in de tweede helft van de jaren dertig 
liep in de steden het protest tegen verkeerslawaai zo hoog op dat het stiller maken van auto's een doel op zich werd. In grote delen van Europa werden daarom dempers voor de uitlaat verplicht gesteld en maxima gesteld aan het aantal decibel dat een claxon en een auto als geheel mochten produceren (Bijsterveld 2001, Bijsterveld 2008).

Sommige ingenieurs wisten dat het gebruik van leer en vilt het autogeluid kon absorberen - veelal geluid in lage frequenties dat via het vele metaal en hout in de auto gemakkelijk werd overgedragen (Snook 1925). Maar eind jaren twintig was die kennis nog geen gemeengoed, en werd het luisteren naar de autoradio zowel door het lawaai van de auto zélf als door interferentie bemoeilijkt. Het resultaat was volgens een tijdgenoot "een helsch lawaai van vervormde klanken, geaccompagneerd door allerlei parasiteerende geluiden." De introductie van screen grid buizen maakte de versterkers meer solide, maar het tegengaan van de interferentie bleek lastiger. Ingenieurs experimenteerden met het inpakken van de ontvanger van de radio, het afschermen van kabels en het aan de motor toevoegen van weerstanden en condensatoren, maar die konden het ontstekingsproces en het rendement van de motor ondermijnen (Autocar 1948: 226). ${ }^{20}$

In de kwestie van de ontstoring stonden de belangen van de autofabrikanten dus tegenover die van de radiofabrikanten. Hetzelfde gold voor de omvang van de batterijen. Omdat de radio veel energie kostte, waren de batterijen binnen de kortste keren leeg. Maar de autoindustrie voelde er niets voor steeds meer zware batterijen aan de auto toe te voegen - dan kwam die auto immers moeizamer vooruit. Philips loste deze spanningen op door in haar ontwerp de radio op de accu van de auto aan te sluiten en aanpassingen aan de motor onnodig te maken door de radioapparatuur zelf minder gevoelig te maken voor storing. ${ }^{21}$ Philips pacificeerde zo de autofabrikanten, al benadrukte Philips voor de zekerheid dat de autoradio niet alleen via garagehouders zou moeten worden verkocht. En terecht. Want nog in 1947 adviseerde de BOVAG eigenaren van garages om bij het verkopen van auto's nooit direct over accessoires als de radio te beginnen. Dat maakte "de wagen maar onnodig duur" (Twist et al. 1947: 212).

Een minstens zo groot probleem was de maatschappelijke onrust die over het gebruik van de autoradio ontstond. Het apparaat was er nog niet of mensen spraken er hun zorg over uit dat het geluid de bestuurders zou afleiden en ongelukken zou veroorzaken, met name in gebieden met een hoge verkeersdichtheid. Daar was het bovendien ook zonder de radio al een lawaaiig gekkenhuis. Verschillende Amerikaanse staten overwogen 
daarom de autoradio te verbieden-helemaal of alleen binnen de stadsgrenzen. Het bestuur van New York was daarnaast zeer verontrust over het gebruik van radio's in taxi's. Taxichauffeurs lieten de radio's op verzoek van passagiers met behulp van een muntje spelen. Maar nadat een oude man door zo'n taxichauffeur was aangereden, werd dit gebruik controversieel. De autoradio zou de aandacht van de chauffeur hebben afgeleid. In de staat Massachusetts had men nog een andere oplossing voor dit probleem. De autoradio zou niet mogen worden aangezet tijdens het rijden, maar wel wanneer de auto voor een picknick of iets dergelijks geparkeerd stond. De maatschappelijke controverse liep zo hoog op dat de Amerikaanse president Herbert Hoover het niet aan de grote klok hing dat hij een autoradio had. Dat zou hem maar partijdig doen lijken. De radio-industrie begon echter een lobby voor de autoradio, en tot een wijdverbreid verbod kwam het niet. ${ }^{22}$

Gedurendeenkelejaren wasechteronzeker hoedeze maatschappelijke controverse precies zou aflopen. Tegen die achtergrond en gezien de kwestie van de ontstoring is het begrijpelijk dat de autoradio in een stilstaande, open auto verhoudingsgewijs veel aandacht van de reclamemakers kreeg, tot in de vroege jaren vijftig. Philips construeerde daarnaast in de vroege propaganda voor de autoradio letterlijk en figuurlijk een eigen ruimte door te benadrukken dat de autoradio niet voor het drukke stadsverkeer, maar voor het platteland was bedoeld. In de stad had de automobilist volgens Philips inderdaad zijn aandacht bij het verkeer nodig. ${ }^{23}$ Bovendien waren Philips medewerkers er in 1931, tijdens een proefrit rond de fabrieken in Eindhoven, achter gekomen dat de ontvangst op de Transitone ook niet zo best was. Smalle straten met hoge gebouwen verhinderden dat. ${ }^{24}$ Buiten de stad bestond dit bezwaar niet, en was het luisteren naar de radio ook niet gevaarlijk, maar juist "een prettige sensatie". 25 Sterker nog: op het platteland zorgde de autoradio er voor dat de bestuurder bij de les bleef. Wie zijn autoradio aan had zou langzamer en dus veiliger rijden dan iemand die niet met de buitenwereld in verbinding stond. ${ }^{26}$

Verkopers van de Philips autoradio werden uitgebreid voorgelicht over hoe ze dit aan hun klanten duidelijk konden maken. ${ }^{27}$ Dat werd dan ook het voornaamste thema in de reclame voor de radio in een rijdende auto: "Een Philips Autoradio veraangenaamt den rit en houdt den geest frisch", aldus een brochure uit $1937 .{ }^{28}$ De autoradio was een "onderhoudende reisgenoot op eenzame tochten", die de automobilist "voor tijdelijke inzinkingen onder het rijden" kon behoeden en "het rijden des avonds tot een genoegen" maakte. ${ }^{29}$ Wie een autoradio 
had, zou nooit meer eenzaam zijn. Eén van de Philips advertenties laat een vrouw zien die in de avond solo achter het stuur zit. Het is akelig donker, maar de vrouw wordt denkbeeldig door een romantisch violist begeleid. ${ }^{30}$ Een dergelijke begeleiding zou de afstand die gereden moest worden aanzienlijk verkorten, zo was de gedachte, en "eentonigheid door veeltonigheid" vervangen. ${ }^{31}$ De "moderne Robinson Crusoë", zo schreef een autojournalist, had in de autoradio zijn "Vrijdag" gevonden. ${ }^{32}$ Andere autojournalisten en radioliefhebbers deelden dat standpunt. Buiten de stad was de autoradio niet "gevaarlijk", maar voorkwam juist-naast een sigaret roken, het raam open zetten of een tukje doen-dat de bestuurder in een staat van "verdooving" raakte.33 (Strepp 1964: 145-148, Dillenburger 1957: 411, 424-425). En voor wie eenmaal wist waar de radiostations precies zaten, vergde het afstemmen "niet meer aandacht dan het aansteken van een sigaret." 34

Bovendien kwam met de autoradio, zo benadrukte Philips, "geheel Europa binnen Uw bereik". Het bedrijf onderbouwde dat ook technisch: in tegenstelling tot Amerikaanse autoradio's was het Philips toestel uit 1934 niet alleen in staat om de korte golf, maar ook de lange golf uitzendingen te ontvangen, wat juist in de Europese context van groot belang was. 35 Zo hield de radio de automobilist "in contact met het wereld gebeuren". ${ }^{6}$ En zoals een Philips advertentie uit 1939, vlak voordat ook Nederland in de Tweede Wereldoorlog betrokken raakte, onderstreepte: "het nieuws dat de radio in deze tijden brengt, is belangrijker dan ooit." 37 Daar kwam bij dat de automobilist met een autoradio op de eerste rang zat bij de concerten, theatervoorstellingen en sportwedstrijden waarnaar hij luisterde. ${ }^{38}$ Op die manier kon hij zelfs twee dingen tegelijkertijd doen: een uitstapje maken en toch het sportevenement niet hoeven missen. 39

Uit een onderzoek onder Zwitserse bezitters van een autoradio, medio jaren vijftig, bleek het thema van de metgezel tijdens lange reizen het meest relevant te zijn. Meer dan de helft van de autoradiobezitters gaf "verstrooiing" tijdens "lange afstanden" op als belangrijkste reden voor het aanschaffen van een autoradio. Het luisteren naar muziek was bij de luisteraars verreweg het meest populair. $4^{\circ}$ En dat terwijl op dat moment de transistor autoradio, FM ontvangst en de radiocassetterecorder nog in het verschiet lagen (Nieuwe 1957, Ruim 1967).

Uit het archief van autoradiofabrikant Philips en uit de vroege autojournalistiek blijkt dus dat de invoering van de autoradio vooraf ging aan het expliciet stiller maken van de auto. Ook is duidelijk dat Philips zowel de techniek van de autoradio als de retoriek van 
de radioverkoop aanpaste aan de bestaande gebruiken, en wel heel snel, tussen 1931 en 1934. Philips maakte met het ontwerp van een accuradio met interne ontstoring een buiging naar de autofabrikanten, en creëerde met de gerichtheid op de lange golf een Europese autoradio. Ook knikte het bedrijf met de radioreclame voor de stilstaande auto naar de maatschappelijke onrust over het afleidend karakter van het apparaat. Hetzelfde gold voor de marketing van de radio als onderhoudende reisgenoot voor de plattelandsrijder. Radioliefhebbers, autojournalisten en consumenten namen dit perspectief over. Toch moesten de technologie van de autoradio en die van het autogeluid nog enkele keren cultureel en maatschappelijk invoegen om van betekenis te blijven. Op naar het tweede invoegmoment.

\section{Luisteren en ontluisteren: de autoradio als stemmingsregelaar}

De betekenis van de autoradio bleef niet stabiel. Terwijl fabrikanten als Philips de autoradio vooral introduceerden als een instrument dat de automobilist letterlijk en figuurlijk met mensen deed omringen, werd de autoradio vanaf de jaren zestig steeds vaker gepresenteerd als een apparaat dat de automobilist kon helpen zijn medeweggebruiker te verdragen en emotioneel op afstand te houden. De omstandigheden op de weg waren tussen de late jaren dertig en de jaren zestig immers veranderd: het autoverkeer was in het Westen enorm toegenomen.

Een Amerikaans animatiefilmpje van Philips uit 1963 laat dat mooi zien. In een "niet zo, maar zo"-scenario wordt eerst een automobilist ten tonele gevoerd die zich met een buitengewoon slecht humeur en agressieve rijstijl door druk verkeer wurmt, zich bont en blauw ergerend aan andere weggebruikers. Dit kan veel beter, beweert het filmpje. Met een Philips autoradio beweegt de automobilist zich in goed gezelschap en dito humeur beleefd door het verkeer. Want wanneer $u$ naar uw favoriete programma's luistert, is het heel gemakkelijk om rustig te blijven. "Uw medeweggebruikers zullen van $u$ houden, en $u$ van ... Philips". 41

Materiaal met deze boodschap werd ook in Nederland en andere Europese landen gebruikt. Daarbij werd benadrukt dat slecht gehumeurd rijden ook onveilig rijden was. "Je kunt je niet bij iedereen en overal op je gemak voelen", zo stond in een Engelstalige brochure, "zeker niet in het huidige vermoeiende verkeer-langzaam, hortend en enerverend als dat is". Een goed humeur was essentieel, en de autoradio bracht dat binnen bereik. ${ }^{42}$ Midden jaren vijftig had Philips de autoradio al voorgesteld als een muzikale paraplu die tegen figuurlijke regenbuien bescherming 
bood. 43 Een dergelijke intimiteit was vanaf het midden van de jaren veertig ook door autofabrikanten opgeroepen. Zij presenteerden de auto als een woonkamer op wielen (Marsch \& Collett 1986: 11, Möser 2002: 240). Maar nu werd de autoradio daar als persoonlijke stemmingsregelaar aan toegevoegd. Wie een autoradio had, kon de buitenwereld aan en zich "verzoenen" met wat hij om zich heen zag. ${ }^{44}$ Verkeersinformatie via de radio, zo onderstreepte de Duitse industrie in de jaren zestig, bood de automobilist bovendien handelingsalternatieven in een wereld waarop hij verder weinig greep had (Weber 2006: 170-173).

Daarmee lijken we op het punt aangekomen dat ik aan het begin van mijn oratie beschreef: dat van de automobilist die via het geluid in zijn auto een gevoel van beschutting en keuzevrijheid krijgt aangereikt dat daarbuiten onder druk is komen te staan. Toch is dit nog niet het hele verhaal. De automobilist kreeg namelijk niet alleen nieuwe luistergebruiken aangereikt, hij moest ook luistergedrag afleren-in sommige opzichten leren ontluisteren. Om dat te kunnen begrijpen, moeten we even terug in de tijd. In de jaren twintig en dertig benadrukten ingenieurs dat afwijkingen in het normale functioneren van auto's vaak al te horen waren voordat men ze kon zien (Snook 1925: 115, Verslag 1936: 77). Dat leidde ertoe dat autohandboeken voor automobilisten gingen uitleggen hoe bestuurders naar hun auto moesten luisteren. Een "niezende" auto had iets te "vertellen" over een obstructie in de mengkamer van de carburator. Een "getraind oor" hoorde dat dit niezen nooit van het ene op het andere moment begon, maar zich aankondigde door een verandering in de hoogte en het ritme van het motorgeluid. "Pingelen" en "kloppen" verhaalden van nog ernstiger problemen (Meyer n.d.: 19, 20, 22, 24, Ganzevoort 1955: 99-100, de Graaf \& de Rétrécy 1961: 109-113, Joppe 1958: 119-120). Een Duitse auteur vergeleek het kloppen van de motor zelfs met een "gedempte paukenslag", en onderstreepte dat automobilisten ieder piepje of kraakje moesten wantrouwen: lawaai kon op schade kunnen duiden-dus op naar de garage! (Dillenburger 1957: 301-303, Bijsterveld 2006).

Een andere Duitse auteur, Alexander Spoerl, wiens boekje in 1963 in het Nederlands op de markt kwam, koos een ander type analogie. Hij vergeleek het proces waarin de automobilist zich ging ergeren aan de akoestische eigenaardigheden van zijn auto met een sleets huwelijk. Bij een flirt "met een meisje, of andermans vrouw, is alles even leuk en prettig. Maar van onze eega gaan allerlei kleinigheden ons steeds meer op de zenuwen werken, totdat wij met moord- of zelfmoordplannen rondlopen. (...) Zo gaat het ook met auto's. Een rammelende taxi is niet 
van ons ... en stoort ons niet in het minst. Zodra wij echter ... met onze eigen wagen getrouwd zijn, begint deze ... ons te hinderen." (...) "Er tikt een klep", de carburator hikt, de motor pingelt, de versnellingsbak kraakt en het "fluit verdacht onder de motorkap". Uw auto "verzwakt" en anderen beginnen $u$ te passeren. Soms zijn die nog "piepjong" (Schoerl 1963: 198-201). Met het huwelijk had deze auteur duidelijk weinig op-overigens geen ongebruikelijk thema in de autoliteratuur. Belangrijker is echter de constatering dat midden jaren zestig het luisteren naar de auto, anders dan daarvoor, niet meer als functioneel werd gezien, maar als iets hinderlijks. Overtollig geluid was ook niet meer de opmaat voor een reparatie, maar voor een nieuwe auto die het gewoon deed.

Door de autoradio te presenteren als stemmingsregelaar in de mobiele huiskamer deed Philips in zijn verkoopstrategie recht aan de toenemende verkeersdruk. Opnieuw voegde de technologie in, zij het dit maal vooral in retorische zin. Philips paste haar marketing dus actief aan de veranderende verkeersgebruiken aan. Tegelijkertijd kregen automobilisten via de autoliteratuur een andere luistercultuur aangeleerd. Zij moesten naar de autoradio luisteren om hun humeur op peil te houden; het geluid van de automechanica was daarentegen niet meer belangrijk. Maar wacht even: als de automobilist niet meer naar zijn auto hoeft te luisteren, waarom vinden autofabrikanten het tegenwoordig dan zo belangrijk dat alles het geluid maakt dat het hoort te maken? Het wordt tijd voor het derde invoegmoment.

\section{Autogeluid in de ervaringssamenleving}

In de jaren zestig en zeventig stelden nationale en Europese overheden steeds stringentere eisen aan de maximale geluidsemissie van auto's (Sandberg 2001). Zowel onder druk daarvan als met het oor op de radio temden autofabrikanten het lawaai van de auto (Stuurt 2007: 6). Maar de auto bleek niet eindeloos stiller te kunnen worden-je moet hem nog wel horen aankomen (Freimann 1993, van Kleef 2002). Zo werd een Noors bedrijf een paar jaar geleden gedwongen manieren te verzinnen om het geluid van de elektrische auto te doen toenemen: de geruisloosheid ervan werd te gevaarlijk (Persoonlijke mededeling Rune Iden). Ook de elektrische sportauto van Tesla Motors werd door gebruikers té stil bevonden. Een ingenieur stelde daarom voor er software in te bouwen "met een keur aan motorgeluiden, net als de ringtones van mobiele telefoons" (Electric 2006: 77). 
Het geluid van de auto blijft er voor fabrikanten en gebruikers dus toe doen. Fabrikanten achten het geluid van motor en uitlaat zelfs cruciaal voor de uitstraling van hun automerk: "De ene vroem is de andere niet" (van der Kwast 2003: 29). En ook wat in de auto te horen valt, bepaalt volgens hen "in sterke mate" de indruk "van de kwaliteit" van een auto (van de Weijer 2007: 9). Het ruisen van de wind, de trillingen van de motor, het contactgeluid van de banden, het hydraulische systeem van de stuurbekrachtiging, het janken van de brandstofpomp-akoestisch ingenieurs pakken het aan, bij voorbeeld via akoestisch glas of het ontwerp van autobanden (Dittrich 2000, Steketee 2006, Kouwenhoven 2002). Technici hebben nog altijd hun handen vol aan het reduceren van het laag-frequente geluid in auto's en moeten steeds opnieuw constateren dat het weghalen van het ene geluid het andere hoorbaar maakt (Stockfelt 1994, Schick 1994, Freimann 1993). Tegelijkertijd willen ze dat schakelaars, waarschuwingssignalen, richtingaanwijzers, het opengaan van de ramen, het dichtklappen van de deur, de motor van de ruitenwissers en het kraken van de leren bekleding het juiste geluid maken. BMW heeft meer dan 150 akoestisch ingenieurs in dienst die ervoor zorgen "dat de motor sportief klinkt, dat de deuren een geruststellend solide geluid produceren ...[en] dat de knoppen met reden klikken" (Jackson 2003: 106, van de Weijer 2007: 9). Bovendien wordt het geluid van de audioapparatuur, aldus Mercedes-Benz, aangepast aan de akoestische omstandigheden in de auto. 45

$\mathrm{Er}$ is dan ook een afzonderlijke onderzoeksindustrie ontstaan die nagaat wat $u$ en ik aangename geluiden vinden (Vetter 2004). Deze zoektocht naar "de heilige graal van de psycho-akoestiek" is echter allesbehalve eenvoudig. De individuele verschillen in preferenties zijn groot, de meningen over de juiste meetmethoden lopen uiteen en mensen blijken het heel lastig te vinden hun voorkeuren op het gebied van geluid verbaal duidelijk te maken-hoe levensecht de simulaties tegenwoordig ook zijn. Die simulaties kosten handenvol geld. Autofabrikanten zeggen inmiddels te weten wat het geluid van een auto moet zijn om "fatsoenlijk", "luxe", "dynamisch" of "sportief" te klinken (Bernhard 2002). Maar ze weten nog niet of deze investeringen in het juiste geluid zich werkelijk in hogere verkoopcijfers zullen terugbetalen (Schick 1994, Fidell 1996, Vetter 2004, Birch 2006).

Waarom steekt de auto-industrie dan toch zoveel tijd en geld in het creëren van merkgebonden geluiden? Het antwoord op die vraag kan gevonden worden in het werk van de Duitse socioloog Gerhard Schulze (1992). In de strategieën voor de verkoop van consumptiegoederen speelt, 
zo onderstreept hij, de zintuiglijke ervaring vandaag de dag een grote rol. Die nadruk op zintuiglijke ervaringen is ontstaan uit de omstandigheid dat veel producten zich zo ver hebben ontwikkeld dat de verschillen in technische prestaties steeds kleiner zijn geworden. Sinds de jaren tachtig doen de meeste producten het gewoon. (We hebben gezien hoe automobilisten al in de jaren zestig op die gedachte werden voorbereid). Bovendien hebben de meeste consumenten een enorme keuze aan consumptieartikelen-de welvaart is na de oorlog immers enorm gestegen. Die vele keuzemogelijkheden creëren echter ook onzekerheid. Om het gebrek aan verschillen in technische kwaliteit te compenseren en de keuze voor consumenten te vergemakkelijken, worden artikelen steeds vaker verkocht door een beroep te doen op de emotionele betekenis en innerlijke ervaring die de producten bij hun kopers kunnen oproepen. In de marketing van nieuwe producten is de zintuiglijke sensatie daarom zeer belangrijk geworden. Het doet er niet alleen meer toe hoe apparaten er uit zien, maar ook hoe ze aanvoelen, ruiken en klinken, en op welke manier dat bij de identiteit van de koper past (Marks 2002: 114, Wenzel 2004). Dit alles heeft tot een sterke esthetisering van het dagelijks leven geleid, iets wat Schulze als het ontstaan van de Erlebnisgesellschaft of ervaringssamenleving karakteriseert.

In de jaren negentig heeft de technologie van het autogeluid zich dus voor een derde keer ingevoegd, dit maal in de ervaringssamenleving. Die ervaringssamenleving is, zo laat Schulze zien, mede het gevolg van technologische ontwikkeling. Maar door invoeging in de ervaringssamenleving zijn auto's ontstaan waarin automobilisten het geluid krijgen dat hen aanspreekt. En geluid kunnen kiezen, zo hebben we gezien, draagt bij aan onze ervaring van controle in de auto en de mogelijkheid ons erin te ontspannen.

\section{De cultuur van innovatie}

Tussen de jaren dertig en de jaren negentig voegde de technologie die het geluid van onze auto-interieurs bepaalt dus verschillende malen in: in de samenleving van de jaren dertig waarin de interferentieproblematiek en het afleidingsgevaar van de autoradio op de agenda stonden, in de hectische verkeerscultuur van de jaren zestig, en in de ervaringssamenleving van de jaren negentig. Pas na het invoegen kon de geluidstechnologie "doorrijden" en bepaalde culturele veranderingen versterken, zoals de gewoonte verschillende activiteiten met elkaar te combineren. Wie geen archiefonderzoek bij een autoradiofabrikant zou hebben gedaan, en zich niet in de cultuur van de jaren dertig, zestig en 
negentig zou hebben verdiept, zou de invoegmomenten niet hebben gezien-zo snel verliepen ze. Wij zien de momenten waarop technologie ritst gemakkelijk over het hoofd. We zijn schijnbaar geruisloos in onze auto's "weg van geluid" geraakt.

De onderzoekers die zich met de ontwikkeling van wetenschap en techniek bezig houden-de beoefenaren van science and Technology Studies (STS) - keren zich al een jaar of twintig tegen het technisch determinisme. Technisch determinisme is de gedachte dat technologie zich autonoom ontwikkelt en de voornaamste motor is van maatschappelijke verandering. Steeds opnieuw hebben STSers echter laten zien dat maatschappelijke omstandigheden vorm geven aan techniekontwikkeling (dat techniekontwikkeling dus niet op zichzelf staat), en hoe nieuwe artefacten in netwerken van techniek en samenleving worden opgenomen (Bijker et al. 1987, Bijker 1995, Latour 1987). Wie het STS-onderzoek serieus neemt, snapt dan ook niet waarom het geloof in technisch determinisme nog zo wijd verbreid is.

Mijn nadruk op de snelheid waarmee technologie zich maatschappelijk invoegt, maakt dat echter wel begrijpelijk. Het ritsen kan in een vloek en een zucht gebeurd zijn-geen wonder dat burgers het gevoel hebben dat technologie hen overvalt. Die geruisloosheid is echter in zoverre schijn, dat in het ritsen veel voorwerk zit. Mijn stelling is dat een fabrikant die een technologische vernieuwing wil laten slagen goede antropologie moet bedrijven. Het bedrijf moet de gebruiken en symbolen van de cultuur waarin het de nieuwe technologie wil laten invoegen gedetailleerd kennen. De kunst en de juiste timing van het innoveren zit hem in het zich voorstellen op welk moment welke handelingen, competenties en betekenissen precies nodig zijn om nieuwe technologie vanzelfsprekend te laten worden.

Dat is niet gemakkelijk. De introductie van de Philips autoradio in de jaren dertig lukte, maar die van de Philips bandrecorder in de jaren vijftig werd in termen van verkoopcijfers niet het succes waarop de fabrikant hoopte. Waar lag dat aan? Philips wilde de bandrecorder verkopen als een familiealbum in geluid, analoog aan het foto-album. Maar het bedrijf liet in advertenties alleen zien hoe het was om familiegeluiden op te nemen, niet hoe het was om die geluiden later met familieleden te delen. En dat bleek bij geluidsbanden veel minder gemakkelijk te zijn dan bij het uitwisselen van foto's: Je had er, anders dan bij foto's, een apparaat voor nodig dat nog altijd werkte, het terugvinden van geluidsfragmenten bleek een heidens karwei, tijdens familiepartijtjes moest iedereen zijn mond houden (niet gezellig), en stemmen bleken 
naar verloop van tijd lastig te herkennen. Philips had zich, met andere woorden, niet verdiept in de cultuur van het bewaren, terugvinden en uitwisselen van tastbare herinneringen in familieverband (Bijsterveld 2004, Bijsterveld \& Jacobs 2008).

Kijken we nog eens vanuit dit perspectief naar de eerste jaren van de Philips autoradio, dan wordt opeens duidelijk waarom dit apparaat wél werd wat Philips hoopte. Door zich te laten informeren over wat de eerste autoradio's in Amerika opriepen-tegen welke maatschappelijke en culturele gewoonten ze aanliepen-en het gebruik ervan in gedachten met Eu ropa te vergelijken, testte Philips het invoegen van de autoradio in de Europese cultuur. Die vergelijking scherpte, zo zou je kunnen zeggen, het culturele voorstellingsvermogen, het antropologisch kunnen van de fabrikant: al bij voorbaat liet Philips zowel het apparaat als de marketing ervan door het perspectief van autofabrikanten en de angst voor afleiding vormen. In het geval van de autoradio bleef Philips bovendien antropologisch alert. Toen de verkeersomstandigheden zich wijzigden, paste het bedrijf ook haar verhaal over de autoradio aan.

Dat wil niet zeggen dat bedrijven alles in de hand hebben. Niet alleen is het voor hen heel moeilijk om goede antropologie te bedrijven, zij zijn niet de enigen die in cultuur en maatschappij proberen in te grijpen. Ook consumentenorganisaties-intermediaire organisaties in vakjargon (de la Bruhèze \& de Wit 2002)—journalisten en liefhebbers van een bepaalde technologie proberen het publiek tot het juiste gebruik van nieuwe technologie op te voeden. Dat kan die technologie de wind in de zeilen geven. Het leren negeren van het geluid van de automechanica was er een voorbeeld van: dat hielp de auditieve gerichtheid op de autoradio. Maar dit type interventies kan ook andere effecten hebben. Zo benadrukte een ANWB-publicatie uit het midden van de jaren dertig braaf dat wie met "een radio-uitrusting in den wagen" de grens over wilde voor ieder land afzonderlijk een luistervergunning moest aanvragen. In Frankrijk moest men tegen betaling van 50 francs "in de eerste plaats, waar men verblijft, het toestel aangeven bij het postkantoor". In Noorwegen hoefde dat pas na drie maanden, maar in België direct, en wel "bij een of ander telegraafkantoor" (ten Broecke Hoekstra 1936: 43). Het is niet waarschijnlijk dat deze informatie de verkoop van de autoradio geholpen heeft.

Wat ik vanmiddag heb gedaan, en wat ik ook in de toekomst hoop te kunnen doen, is in feite het uitvoeren van archeologisch onderzoek naar andermans antropologie, naar de geschiedenis van de cultuurverkenningen die nodig zijn om technologie in te laten voegen. 
Dat is wat we binnen onze faculteit het onderzoek naar de cultuur van innovatie hebben genoemd, althans dat is de manier waarop ik dat thema handen en voeten wil geven.

Onderzoek naar de cultuur van innovatie maakt het nodig om reclamemateriaal te analyseren, maar ook om archiefonderzoek te doen naar wat er op het niveau van bedrijven gebeurt vóórdat de officiële reclamecampagnes van start gaan. Daarbij is het belangrijk oog te hebben voor de innoverende rol van marketing in de vroegste geschiedenis van nieuwe technologie. Omdat STS zich er lange tijd op heeft gericht te laten zien dat technologie-ontwikkeling méér is dan een Eureka-moment, méér dan de individuele uitvinding in een vlaag van helder inzicht, is het onderzoeken van creativiteit in de vroegste fasen van techniekontwikkeling wat uit de mode geraakt. Niettemin hebben de makers en verkopers van nieuwe technologie, zo hebben we gezien, die creativiteit wel degelijk nodig. Ze moeten rekening houden met maatschappelijke gebruiken en culturele associaties. Zo is de symbolische associatie van lawaai met kracht cultureel gezien zo diepgeworteld, dat de makers van stille producten zich tot op de dag van vandaag moeten verdedigen tegen de beschuldiging dat hun apparaten niet krachtig genoeg zijn (Wolkomir 1996). Maar de makers en verkopers van nieuwe technologie kunnen oude culturele connotaties ook op nieuwe, creatieve manieren inzetten, zoals de gedachte dat stille auto's slim zijn.

Omdat het al dan niet slagen van een nieuwe technologie echter niet alleen afhankelijk is van wat bedrijven doen, is het daarnaast zinnig het type materiaal te bestuderen dat ik verschillende keren heb genoemd: krante-en tijdschriftartikelen van en gericht op de consument, alsook de literatuur die tot doel heeft mensen de competenties te leren die nodig zijn om met een bepaalde technologie om te gaan. En zelfs dat is nog niet genoeg. Ik zou de zoektocht naar merkgebonden geluid in de huidige auto-industrie niet hebben begrepen als ik Schulze's theorie over de ervaringssamenleving niet zou hebben gekend. Dat betekent dat het onderzoek dat ik doe nooit de technologie als eenheid van onderzoek heeft, maar de maatschappelijke kwesties en culturele betekenissen waarin technologie invoegt. En dat ik voor het begrijpen van die kwesties en betekenissen theorieën uit verschillende disciplines nodig heb.

Maar voor ik tot mijn dankwoord overga: de hamvraag. Waarom is het belangrijk het ritsen van technologie te ontsluieren? Waarom had ik na mijn psychologische verklaring voor de positie van de auto als oord van rust nog een archeologie van andermans antropologie nodig? Omdat de rol van cultuur volkomen wegvalt op het moment dat het gebruik 
van een technologie algemeen aanvaard is geraakt. We vergeten de competenties die we hebben moeten leren zodra we die ons hebben eigen gemaakt. Hun tijdgebondenheid blijkt uit de voorbije opmerking dat het afstemmen op een autoradiostation even veel tijd kost als het opsteken van een sigaret. Is het gebruik van een technologie eenmaal gewoon, dan zijn psychologische verklaringen relevant. Maar dergelijke verklaringen helpen niet om te begrijpen hoe we zo ver zijn gekomen. Daarvoor is inzicht nodig in de manieren waarop technologie zich cultureel en maatschappelijk invoegt. Bovendien geeft het systematisch vergelijken van invoegmomenten ons inzicht in de mechanismen achter het succes en falen van technologie, bij voorbeeld in de redenen waarom bedrijven soms wel en soms geen goede antropologen zijn. Daar kunnen bedrijven hun voordeel mee doen. Maar we zijn ook als aanstaande kopers van technologie gewaarschuwd: kan ik dit apparaat, deze technologie werkelijk in mijn bestaan, in mijn persoonlijke cultuur inbedden? Voor wie nog inkopen moet doen voor de feestdagen: misschien heeft $u$ er wat aan...

En dan nog dit: psychologische verklaringen zijn relevant om te begrijpen waarom onze auto tegenwoordig een plaats is om tot rust te komen. Dat maakt het ook begrijpelijk waarom we er in blijven rijden. Maar zouden we daarvan af willen, of het carpoolen willen stimuleren, dan is opnieuw cultuurwetenschappelijk onderzoek naar onze gebruiken nodig, naar de competenties die we zouden moeten hebben om de positie van de auto te veranderen.

\section{Dankwoord}

Dames en heren, het wordt tijd voor een bekentenis. Voor wie het nog niet weet: ik rijd geen auto. Vanwege mijn verstrooidheid en onvermogen diepte te zien is die afwezigheid van een rijbevoegdheid volgens velen in het belang van de volksgezondheid. Toch komt het schrijven over de auto niet voort uit compensatiedrang-ik ben gewoon weg van geluid. ${ }^{46}$ Daarom begin ik met het bedanken van de mensen in mijn omgeving die veel geluid produceren, mijn medemuzikanten in Raak, Quartna en Arka. Van jullie klanken rust ik na gedane arbeid uit. Temidden van orkesten, koren en ensembles zijn bovendien, lang geleden en meer recent, vele dierbare vriendschappen ontstaan.

Dat ik mijn interesse voor geluid tegenwoordig met een baan aan de universiteit kan combineren is aan verschillende mensen te danken. Toen ik in Groningen bij Doeko Bosscher in de contemporaine geschiedenis afstudeerde, zei hij iets wat nog lang bleef nagalmen. Ik 
had een keurige scriptie geschreven, zo vond hij, maar in de stijl ervan miste hij het musische-terwijl dat musische er gezien mijn orkestleven wel degelijk moest zijn. Ik ben hem die opmerking zeer dankbaar, al heeft het even geduurd voor ik er iets mee durfde te doen.

Paul Thung was mijn scriptie-begeleider in Maastricht. Alleen al door mij erop te wijzen dat er in Maastricht promotieplaatsen vrij kwamen, maakte hij het gemakkelijker ook daadwerkelijk naar zo'n plaats te solliciteren. Dat werd er één bij Gerard de Vries en Rein de Wilde. Zij bleken een soortgelijke boodschap te hebben als Doeko. Ze waardeerden het zéér dat ik zoveel archieven uitgroef, maar als filosofen zagen ze toch liever een onsje minder braafheid en een kilo meer aan lef. Gerard en Rein-dat ik tegenwoordig met grotere stappen sneller thuis ben, ondanks een hoger gewicht, is aan jullie te danken.

Aardige bazen heb ik altijd gehad, om te beginnen Taco Kastelein bij de faculteit Economie in Groningen, wiens student-assistent ik was. Hij is helaas overleden, maar onze urenlange gesprekken over het academisch leven waren van een genoeglijkheid die ik niet vergeten ben. Hetzelfde type vaderlijke beminlijkheid heeft Wiebe Bijker. Wiebe: je bent de ideale mentor en hebt me meer kansen gegeven dan ik kon aannemen. Zo heb je de deuren geopend naar het directeurschap van WTMC, dat ik met ontzettend veel plezier uitvoer omdat de WTMC leden en -promovendi zo kleurrijk zijn. En ik heb er opnieuw met een leidinggevende te maken die niets dan goede adviezen geeft: bestuursvoorzitter Nelly Oudshoorn. Het directeurschap van WTMC bracht het bijzonder hoogleraarschap op mijn weg. Die benoeming was in handen van de decaan van de faculteit Cultuurwetenschappen van ruim twee jaar geleden, Paul Tummers, en de huidige leden van het College van Bestuur. Ik dank hen daarvoor hartelijk.

Ik ben dol op de kelders en zolders waar ik in alle eenzaamheid tussen oude papieren kan snuffelen. Als ik daar dan later maar met anderen over kan kletsen. Dat kon volop in de projecten waarin ik met studenten en collega's samen schreef aan artikelen, boeken of onderzoeksvoorstellen. Voor hun enthousiasme en gezelligheid dank ik: Monique Stavenuiter, Klasien Horstman, Jessica Mesman, Carla Hillekens, Yvette Bartholomée, Marten Schulp, Trevor Pinch, José van Dijck, Andreas Fickers, Gijs Mom, Kristin Vetter, Annelies Jacobs, en-nogmaals: Wiebe.

Lieve ouders: het kan onmogelijk aan jullie liggen dat ik me nu met auto's bezighoud. Als er iets was wat jullie niet interesseerde, dan waren het auto's. Zo reed ons gezin jarenlang in een goedkope Trabant-de kosten zaten hem vooral in de wegenwacht. Terwijl we uitkeken naar 
de ANWB, maakten we liedjes, hardop of inwendig. Er rijmde veel op Trabant: tramelant, langs de kant, we zijn weer diep in 't land verzand met de Trabant. Nee, dan de liefde voor lezen, schrijven, muziek maken en geld uitgeven aan alles wat ook maar enigszins cultureel verantwoord lijkt. Dat is een belangrijk deel van jullie wereld en het is ook de mijne geworden. En dat is dan nog maar een fractie van wat ik van jullie aan goeds meekreeg. Twee leuke zussen bij voorbeeld: Aletta bewonderenswaardig rustig en Binda opmerkelijk geestig.

Lieve Rein: sinds je rolwisseling van promotor naar geliefde ben ik op de universiteit ook letterlijk sneller thuis. Maar ik ben tegelijkertijd meer op weg. Toen ik in jouw private wereld was opgenomen, zat ik opeens aanmerkelijk vaker in de auto. Auto rijden was voor mij zo ongewoon, dat ik niet onmiddellijk doorhad dat onze langdurige aanwezigheid op de linkerbaan niet geheel overeen kwam met mijn neiging de regels te respecteren. Dat ik toch graag naast jou in de auto zit-ja, dát is nu romantiek. En lieve Sarah, al heeft de universiteit voor Rein en mij iets huiselijks, het leukste thuis is waar jij bent.

\section{Slot: nooit meer te weinig onderzoekstijd}

Tot slot nog dit. De vaakst geuite klacht op de universiteit is dat we te weinig tijd voor onderzoek hebben. Onderzoeker zijn betekent dan, zoals Sarah zei toen ze een jaar of tien was: "op je kamer in je eentje achter een computer zitten en naar huis gaan als je collega's je te veel storen". En laten we eerlijk zijn, deze vorm van intellectuele privacy proberen we inderdaad vaak te bereiken. We vinden nog steeds dat we recht op stilte hebben. Maar we maken het ons daarmee niet gemakkelijk. Want onderzoek doen is ook: op een receptie van een nieuw artikel horen, onder de lunch de academische wereld doornemen, tijdens een stagegesprek een onderzoeksvraag bedenken, en op vakantie aan de rand van het zwembad met de onbekende man naast je tot wederzijds genoegen na vijf zinnen uitkomen bij de nieuwste ontwikkelingen in de elektrische auto. Zo opgevat is onderzoeker zijn ook veel eenvoudiger met het leven in het algemeen te combineren dan het vaak lijkt. Kortom: het is tijd voor de borrel, het is tijd voor onderzoek. 


\section{Literatuurlijst}

Alexander, J.W. (1938).

Auto-radio. Philips Technisch Tijdschrift, 1, april , 113-119.

Altman, Irwin (1976).

Privacy. A Conceptual Analysis. Environment and Behavior, 8, 1, 7-29.

Autocar (1948).

The Autocar Handbook for the Motorist. London [etc.]: Iliffe \& Sons Ltd.

Berger, Michael L. (1979).

The Devil Wagon in God's Country. The Automobile and Social Change in Rural America, 1893-1929. Hamden, Connecticut: Archon Books.

Bernhard, Ulrich (2002).

Specific development of a brand sound. In AVL Engine and Environment 2002 (pp. 103-115). [Graz: AVL Company].

Bijker, Wiebe E., Hughes, Thomas P. \& Pinch, Trevor (1987).

The Social Construction of Technological Systems. Cambridge, MA: The MIT Press.

Bijker, W.E. (1995).

Of Bicycles, Bakelites, and Bulbs. Toward a Theory of Sociotechnical Change. Cambridge, MA: The MIT Press.

Bijsterveld, Karin (2001).

The Diabolical Symphony of the Mechanical Age. Technology and Symbolism of Sound in European and North American Noise Abatement Campaigns, 1900-40. Social Studies of Science, 31, 1, 37-70.

Bijsterveld, Karin (2004)

"What Do I Do with My Tape Recorder...?": Sound Hunting and the Sounds of Everyday Dutch life in the 1950 s and 1960s. Historical Journal of Film, Radio and Television, 24, 4, 614-634.

Bijsterveld, Karin (2006).

Listening to Machines: Industrial Noise, Hearing Loss and the Cultural Meaning of Sound. Interdisciplinary Science Reviews, 31, 4, 323-337.

Bijsterveld, Karin (2008).

Mechanical Sound: Technology, Culture and Public problems of Noise in the Twentieth Century. Cambridge, MA: The MIT Press (Forthcoming, July). 
Bijsterveld, Karin \& Jacobs, Annelies (2008).

Storing Sound Souvenirs. The Contested Domestication of the Reel-to-Reel Recorder. In Karin Bijsterveld \& José van Dijck (Eds.). Sound Souvenirs: Audio Technologies, Memory, and Cultural Practices. Amsterdam: Amsterdam Universty Press (Forthcoming).

Birch, Stuart (2006).

Good Vibrations. Automotive Engineering, 114, 9, 46-50.

Broecke Hoekstra, B. ten (1936).

Met de auto op reis. Amsterdam: Kosmos.

Bruhèze Adri A.A. de la \& Wit, Onno de (2002).

De productie van consumptie. De bemiddeling van productie en consumptie en de ontwikkeling van de consumptiesamenleving in Nederland in de twintigste eeuw. Tijdschrift voor Sociale Geschiedenis, 28, 3, 257-272.

Bull, Michael (2003).

Soundscapes of the Car: A Critical Study of Automobile Habitation. In Michael Bull \& Les Back. The Auditory Culture Reader (pp. 357-374). Oxford [etc.]: Berg.

Bull, Michael (2004).

Automobility and the Power of Sound. Theory, Culture and Society, 21, 4/5, 243-259.

Butsch, Richard (2000).

The Making of American Audiences: Fom stage to television, 1750-1990. Cambridge [etc.]: Cambridge University Press.

DeNora, Tia (2000).

Music in Everyday Life. Cambridge: Cambridge University Press.

Dillenburger, H. (1957).

Das praktische Autobuch. Gütersloh: G. Bertelsmann Verlag.

Dittrich, Michael (2001).

Sound of silence. In TPD in 2000-projecten (p. 18). Delft: TPD.

Douglas, Susan J. (1999).

Listening In. Radio and the American Imagination, from Amos ' $n$ ' Andy and Edward R. Murrow to Wolfman Jack and Howard Stern. New York: Times Books.

Electric (2006).

Electric Cars. The Economist, July 29, 77. 
Fidell, Sanford (1996).

Questing After the Holy Grail of Psychoacoustics...Again! Sound and Vibration, 30 , 5, 18-23.

Freimann, Raymond (1993).

Das Auto-Klang statt Lärm. In Langenmaier, Arnica-Verena (Red.), Der Klang der Dinge (pp. 45-57). München: Verlag Silke Schreiber

Ganzevoort, A.W. (1955).

De auto en zijn baas. 's-Gravenhage/Bandung: N.V. Uitgeverij W. van Hoeve.

Graaf, P. de \& Rétrécy, H. de (1961).

Wij en onze auto. Zwolle: La Rivière \& Voorhoeve (originally published by Westrup, Arthur, Im Auto Zuhause. Bielefeld: Verlag Delius, Klasing \& Co.).

Groot, Ger (2005).

Auto-luisteren. De Groene Amsterdammer, 2 december, 45.

Jackson, Daniel M. (2003).

Sonic Branding. An Introduction. Houndmills [etc.]: Palgrave Macmillan.

Jong, R.G. de, Steenbekkers, J.H.M. \& Vos, H. (2000).

Hinder en andere zelf-gerapporteerde effecten van milieuverontreiniging in Nederland. Leiden: TNO.

Joppe, Jaap (1958).

Prisma Autoboek. Vraagbaak voor de automobilist of voor wie het wil worden. Utrecht/Antwerpen: Het Spectrum.

Katz, Mark (2004).

Capturing Sound: How Technology has Changed Music. Berkeley and Los Angeles: University of California Press.

Klawitter, Gerd, Patrick Amann \& Frank Dröger (2005).

Autoradios. Praxistipps zu Turnern, Car-Hifi, Zubehör und Multimedia. Geschichte, Gegenwart und Zukunft. Baden-Baden: Verlag für Technik und Handwerk GmbH.

Kleef, Bas van (2002).

Sluipmoordenaar. Volkskrant Magazine, 8 juni, 41.

Kouwenhoven, Erik (2002).

Autoband moet fluisteren. Algemeen Dagblad, 4 mei, 43.

Kwast, Paul van der (2003).

De vroem-fabriek. Intermediair, 6 februari, 29. 
Latour, Bruno (1987).

Science in Action. How to Follow Scientists and Engineers through Society. Milton Keynes: Open University Press.

Lieshout, Marcel van (2007).

De file als weldaad. De Volkskrant, 27 september, Voorkant, 15.

Manguel, Alberto (1999).

Een geschiedenis van het lezen. Amsterdam: Ambo.

Marks, Laura U. (2002).

Touch. Sensuous Theory and Multisensory Media. Minneapolis/London: University of Minnesota Press.

Marsch, Peter \& Collett, Peter (1986).

Driving Passion. The Psychology of the Car. London: Jonathan Cape.

McShane, Clay (1994).

Down the Asphalt Path. The Automobile and the American City. New York: Columbia University Press.

Merki, Christoph Maria (2002).

Der holprige Siegeszug des Automobils 1895-1930. Zur Motorisierung des Strassenverkehrs in Frankreich, Deutschland und der Schweiz. Wien [etc.]: Böhlau.

Meyer, H. [no date, probably 1930s].

Achter het Autostuur. Wenken in het belang van rijder en mechanisme. Amersfoort: Valkenhoff \& Co.

Mom, Gijs (1997).

Geschiedenis van de auto van morgen. Cultuur en techniek van de elektrische auto Deventer: Kluwer Bedrijfsinformatie.

Möser, Kurt (2002).

Geschichte des Autos. Frankfurt/New York: Campus Verlag.

Nieuwe (1957).

Nieuwe ontwikkeling van autoradio. Philips Mededelingen, januari 1957, nr. A5.

Oel, Justus van (2005).

Liever de Hummer dan de trein. Want de auto laat zien wie wij zijn. NRC Handelsblad, Opinie \& Debat, 1 oktober, 13.

Otterspeer, Willem (2000).

Het bolwerk van de vrijheid: de Leidse universiteit, 1575-1672. Amsterdam: Bert Bakker. 
Paassen, Daphne van (2004).

Mobiel daten voor forensen. Intermediair, 48 (23 November), 31.

Peters (2006).

Time, Innovation and Mobilities. London: Routledge.

Ruim (1967).

Ruim 30 jaar geleden verscheen eerste autoradio-ontvangtoestel. Philips Koerier, 2 september 1967, 10-11.

Sandberg, Ulf (2001).

Abatement of traffic, vehicle, and tire/road noise-the global perspective. Noise Control Engineering Journal, 49, 4, 170-181.

Schick, August (1994).

Zur Geschichte der Bewertung vond Innengeräuschen in Personenwagen. Zeitschrift für Lärmbekämpfung, 41, 3, 61-68.

Schiffer, Michael B. (1991).

The Portable Radio in American Life. Tucson/London The University of Arizona Press.

Schulze, Gerhard (1992).

Die Erlebnisgesellschaft. Frankfurt/New York: Campus Verlag

Smit, Wim A. \& Ellen C.J. van Oost (1999).

De wederzijdse beïnvloeding van technologie en maatschappij. Een Technology Assessment-benadering. Bussum: Coutinho.

Snook, Clyde (1925).

Automobile-Noise Measurement. The Journal of the Society of Automotive Engineers, 17, 1, July, 115-124.

Spoerl, Alexander (1963).

Geen angst voor pech onderweg. Amsterdam/ Brussel: Elsevier (Oorspronkelijk gepubliceerd onder de titel Der Panne an den Kragen. Munchen: R. Piper \& Co. Verlag).

Steketee, Menno (2006).

Hightech autoruit. Elsevier Thema Auto, April, 68-69.

Stevens, Handley (2004).

Transport Policy in the European Union. Houndsmill/New York: Palgrave McMillan.

Stockfelt, Ola (1994).

Cars, Buildings and Soundscapes. In Järviluoma, Helmi (Ed.) Soundscapes. Essays on 
Vroom and Moo (pp. 19-38). Tampere: Tampere University.

Strepp, Hansgeorg (1964).

Veilig autorijden. De kennis. De kunst. De psychologie. Utrecht/Antwerpen: Prismaboeken.

Stuurt (2007).

Stuurt strak door de bocht en blaast supersound in je oren. NRC Handelsblad, Thema Auto's, 24 maart, 6.

Twist, G. van, Hardonk, J \& Sadée, A.E.M. (1947).

Het automobiel-en garagebedrijf. Haarlem: Boom-Ruygrok N.V.

Urry, John (1999).

Automobility, Car Culture and Weightless Travel: A discussion paper, published by the Department of Sociology, Lancaster University, Lancaster LA1 4YN, UK, at http://www.comp.lancs.ac.uk/sociology/papers/Urry-Automobility.pdf

Urry, John (2000).

Inhabiting the Car, published by the Department of Sociology, Lancaster University, Lancaster LA1 4YN,UK, at http://www.comps.lancs.ac.uk/sociology/ papers/Urry-Inhabiting-the-Car.pdf

Verslag (1936).

Verslag van het tweede Anti-Lawaai-Congres te Delft op 21 april 1936 georganiseerd door de Koninklijke Nederlandsche Automobiel Club en de Geluidstichting. Delft: Geluidstichting.

Vetter, Kristin (2004).

Humming, Hissing \& Human Values-Sound Evaluation Tests in Car Acoustics as Mediators between Technological Artifacts, Scientific Methods and Culture. Maastricht: Master Thesis/ The European Inter-University Association on Society, Science and Technology.

Volti, Rudi (2004).

Cars and Culture. The Life Story of a Technology. Baltimore: The Johns Hopkins University Press.

Weber, Heike (2006).

Mobile Freiheit: Überall und Jederzeit: Nutzungsideen, Gestaltung und Verwendung tragbarer Konsumelektronik in der zweiten Hälfte des 20. Jahrhunderts. Berlin: Unpublished PhD Thesis.

Weijer, Bard van de (2007).

Kalm tuffen of bronstig cruisen. De Volkskrant, 3 februari 2007, 9. 
Wenzel, Silke (2004).

Vom Klang zum Lärm. Neue Zeitschrift für Musik, 165, 2, 34-37.

Wiethaup, Hans (1966).

Lärmbekämpfung in historischer Sicht. Vorgeschichtliche Zeit - Zeitalter der alten Kulturen usw. Zentralblatt für Arbeitsmedizin und Arbeitsschutz, 16, 5, 120-124.

Wolkomir, Richard (1996).

Decibel by Decibel, Reducing the Din to a Very Dull Roar. http://www.acoustics. org/swag6o2.html (16 augustus 2001). 


\section{Eindnotes}

1 Zelfs de stilte is standaard (1999). [Commercial Toyota Avensis, videotape]. Talmon: AV Communicatie.

2 Business Travel (1990). [Commercial Mercedes-Benz, videotape]. Stuttgart: DaimlerChrysler AG, en Blind Brothers Three (1999). [Commercial Volkswagen Passat, videotape]. Almere: TeamPlayers. Met dank aan R. Frenken, voormalig student Cultuur- en Wetenschapsstudies, Universiteit Maastricht.

3 Let your car do the talking [tijdschrift-advertentie Chrysler Voyager, gepubliceerd tussen 2002 en 2007].

4 De nieuwe FordFocus. Voel de verfijning. Dagblad de Limburger, 24 januari 2005, B11.

$5 \cup$ rijdt geen diesel, u rijdt Jaguar [2006]. Beesd: Jaguar Nederland.

6 Honda: The Power of Dreams (2005). Aalsmeer: Honda Nederland BV, p. 12.

7 Een mens krijgt 469.082 geluidsprikkels per minuut (1999). Elsevier, 23 oktober, 12-14.

8 Zie hiervoor de website van het Ministerie van Volkshuisvesting, Ruimtelijke Ordening en Milieubeheer http://www.vrom.nl/pagina.html?id=17855 (21 augustus 2007).

9 Het slimste jongetje van de klas (2006). Elsevier, 27 juli, 24 augustus, en 21 september (publikatiedata op basis van mondelinge informatie ChevroletGeneral Motors, hoofdkantoor Nederland, 21 augustus 2007).

10 Zie Linda Steg, geciteerd in Van Paasen 2004: 31, en Cees Wildervanck, geparafraseerd in Van Lieshout 2007: 15.

11 Bull baseerde zijn uitspraken op interviews met en dagboeken van 87 Britse automobilisten.

12 Michael Bull spreekt van "Sonic Envelope" (Bull 2004: 247), en John Urry van "mobile capsule" (Urry 1999: 9). Uiteraard heeft niet alleen de toenemende controle over het geluid in de auto aan het ontstaan van de mobiele capsule bijgedragen. Dat geldt ook, zo stelt Urry terecht, voor de airconditioning, automatisch schakelen, cruise control,en allerlei vormen van informatievoorziening in de auto (Urry 2000: 6).

13 Philips Company Archives (PCA), Dossier 811.215, 1928-1932, handgeschreven briefje met een verwijzing naar de Radio Express van 30 November 1928. Het briefje is vermoedelijk afkomstig van de Philips correspondent in de Verenigde Staten L.P. Graner. Zie ook uit Radio-Nieuws: In iedere auto een radiotoestel [ongedateerd, 1928 of 1929].

14 PCA, Dossier 811.215, 1928-1932, Brief L.P. Graner aan P. Staal, 21 mei 1929.

15 PCA, Dossier 811.215, 1933 e.v., C. Tindal, Auto en Radio, Het Motorrijwiel en de Populaire Auto, 16 februari 1934, 196-198, p. 196.

16 Mijn keuze om me op het voorbeeld van de Philips radio te concentreren, komt ondermeer voort uit het besef dat Philips een relatief belangrijke speler op de Europese markt voor autoradio's was. In 1956 was in Zwitserland bij voorbeeld 31 procent van de autoradio's die op dat moment in gebruik waren afkomstig van Philips, tegen 12 procent van Blaupunkt, 4 procent van Becher en 4 procent van Philco. Zie: PCA, dossier 811.215, Autoradio's, map 1 (1947-1974). De markt voor autoradio's in personenauto's in Zwitserland, p. 2. 
17 PCA, Videomateriaal, The Secrets of His Power, 1952.

18 PCA, Dossier 812.215, Foto's van reclamemateriaal, 1934-1960, afbeeldingen 1934, 1939, 1949, 1953, en PCA, Dossier 811.215, Product Documentatie Autoradio's, Philips Auto Radio “Tips”, nr. 5, Mai-Juni 1936, afbeelding volgend op pagina 1.

19 Bij introducties van nieuwe autoradiotechnologie, zoals de transistor-autoradio, keerde de cabriolet ook steeds in reclame-uitingen terug.

20 PCA, Dossier 811.215, 1933 e.v., W.Vogt, Radio in een Auto, De Auto [15 februari 1934], p. 253; Th.P. Tromp, Rapport No. 1 Reis Amerika, 16 februari 1934. Zie ook PCA, Dossier 811.215, 1928-1932, The New York [Sun] Radio [Section], Installs Radio in Car With Good Results, 7 december 1929; Brief L.P. Graner aan P. Staal, 21 mei 1929; brief L.P. Graner aan N.V. Philips' Radio, Eindhoven, 20 december 1929; Lynch, Arthur H., Radio takes the open road [1930]; Mahanay, Stuart C. How to Install an Auto-Radio Receiver, Radio News, februari 1930, 722-723; Jedes Auto ein Radioapparat, Radiowelt, 9-15 maart 1930; Putting Radio Sets in Automobiles, The New York Sun Radio Section, April 19, 1930; Smits, W.H. (1932). Radio-ontvangtoestellen in automobielen. Polytechnisch Weekblad, 26, No. 17.

21 PCA, Dossier 811.215, 1933 e.v., Th.P. Tromp, Rapport No. 1 Reis Amerika, 16 feburari 1934, p. 3. Om de autoradio te kunnen voeden via de accu van de auto werd aan de radio een nieuw type triller toegevoegd voor het omzetten van de spanning. Ook informeerde Philips garagehouders over de storing die niet via de motor, maar bij voorbeeld via de wielen ontstond.

22 PCA, Dossier 811.215, 1928-1932, brief L.P. Graner aan N.V. Philips' Radio, Eindhoven, 20 december 1929; Putting Radio Sets in Automobiles, The New York Sun Radio Section, April 19, 1930; Bruno, O. Automobil und Radio, Radiowoche, No. 19, 7 mei 1930, p. 3; Brief L.P. Graner aan N.V. Philips' Radio, Eindhoven, 13 juni 1930. Zie ook: PCA, Dossier 811.215, 1933 e.v., Knipsel 19 september 1934, Het Volk, Autoradio gevaarlijk op den weg?; Dossier 811.215, Product Documentatie Autoradio's, Vijftig jaar Philips autoradio, Philips Koerier, 12 april 1984, p. 5.

23 PCA, Dossier 811.215. Product Documentatie Autoradio's, Philips Auto Radio “Tips", nr. 5, Mai-Juni 1936, p. 2; Dossier 811.215, 1933 e.v., Knipsel 19 september 1934, Het Volk, Autoradio gevaarlijk op den weg?

24 In Amerika bedierven ook de metalen bruggen van treinen de ontvangst. Telefoon- en trolleylijnen konden de ontvangst daarentegen verbeteren. PCA, Dossier 811.215, 1928-1932, Putting Radio Sets in Automobiles, The New York Sun Radio Section, April 19, 1930.

25 PCA, Dossier 811.215, 1928-1932, Radio in auto. Demonstratie op Dinsdag 5 mei, door den Heer Keurborst, vertegenwoordiger der Crysler Corporation, Verslag Van Thijn, 6 mei 1931.

26 PCA, Dossier 811.215, Product Documentatie Autoradio's, Philips Auto Radio "Tips", nr. 5, Mai-Juni 1936, p. 3.

27 PCA, Dossier 811.215, Product Documentatie Autoradio's, Storingen, veroorzaakt door ontladingen van statische electriciteit in de wielen, 1937, p. 7

28 PCA, Dossier 811.215, 1933 e.v., Philips Auto Radio: Geeft ontspanning en vergroot de aandacht voor den weg, September 1935.

29 PCA, Dossier 811.215, DA Multomap, Met Philips Autoradio geheel Europa binnen Uw bereik, 1933; PCA, Dossier 811.215, 1933 e.v., Van de Veluwe naar Londen 
in een handomdraai, 1 juni 1939.

30 PCA, Dossier 811.215, Product Documentatie Autoradio's, Philips Auto Radio "Tips", nr. 5, Mai-Juni 1936, Voorpagina.

31 PCA, Philips advertenties, 1960-1969, Bent u vaak alleen met die streep op de weg? Algemeen Handelsblad, 10 mei 1960. Zie ook: PCA, Dossier 812.215, Foto's van reclamemateriaal, 1934-1960, “Cut a long way short", en Display 27 November 1954, C46528, "Les kilomètres sont plus courts avec un autoradio Philips".

32 PCA, Map Philips Advertenties Autoradio 1960-1969, advertenties Algemeen Handelsblad, 10 mei 1960 en 2 mei 1962; . PCA, Dossier 811.215, 1933 e.v., Europa tussen de bumpers, Auto-transport [1936], 125-127, p. 125.

33 PCA, Dossier 811.215, 1933 e.v., Knipsel 19 september 1934, Het Volk, Autoradio gevaarlijk op den weg?; Knipsel September 1936: Voor garage en wagen, Autotransport, p. 261. Zie ook: PCA, Dossier 811.215, 1933 e.v., C. Tindal, Auto en Radio, Het Motorrijwiel en de Populaire Auto, 16 februari 1934, 196-198, p. 197-198, en M.W.H. de Gorter, Is Auto-radio Gevaarlijk? De Installateur, 21 April 1934, 124-[125]; Knipsel 1 april 1937, De Auto, Radioklanken rond het stuurwiel.

34 PCA, Dossier 811.215, 1933 e.v., Philips'Autoradio, Is radio in auto's gevaarlijk? September 1935 .

35 PCA, Dossier 811.215, 1933 e.v., Philips radiotoestellen doen hun intrede in de auto!, De Auto [15 februari 1934], p. 256. Zie ook: Alexander (1938).

36 PCA, DA multomap [met Philips advertenties en brochures over de autoradio], "Met Philips Autoradio geheel Europa binnen Uw bereik", 1933.

37 PCA, Dossier 811.215, 1933 e.v., Wanneer neem jij zoo'n autoradio?

38 PCA, Dossier 811.215, Product Documentatie Autoradio's, Philips Auto Radio “Tips", nr. 2, September-October, 1937, Voorpagina en p. 14. Dit thema sloot nauw aan bij de manier waarop eerder de grammofoon en de radio waren verkocht: met de grammofoon of radio konden consumenten in alle rust thuis als in een luxe loge zitten luisteren (Katz 2004, Douglas 1999).

39 PCA, Dossier 811.215, Product Documentatie Autoradio's, Philips Auto Radio “Tips”, nr. 2, September-October, 1937, p. 14.

40 PCA, dossier 811.215, Autoradio's, map 1 (1947-1974). De markt voor autoradio's in personenauto's in Zwitserland, respectievelijk p. 2, pp. 16-17. Zie ook: De autoradio en de gebruiker, 2 januari 1957, p. 6. Van de autoradiobezitters luisterde 78 procent het liefst naar muziek. Daarnaast luisterde 24 procent (ook) graag naar het nieuws.

41 PCA, Videomateriaal, “Stop...go”, 1952. Alle citaten uit het Duits, Frans en Engels die in deze rede worden aangehaald, zijn door de auteur vertaald.

42 PCA, Dossier 812.215, Foto's van reclamemateriaal, 1934-1960, Philips all-transistor car radio, 5. 1963. Zie ook: PCA, Dossier 811.215, Product Documentatie, Philips Autoradio, Gute Laune unterwegs, 1964.

43 PCA, Dossier 812.215, Foto's van reclamemateriaal, 1934-1960, ontwerptekening reclame 1956.

44 PCA, Dossier 811.215, 1933 e.v., Philips Autonieuws, februari 1965; PCA, Dossier $811.215,1933$ e.v., Mogelijkheden voor autoradio's, Financieel Dagblad, 30 augustus 1966, p. 7. 
45 http://www/mercedes-benz.com/e/innovation/fmobil/maybach 03.htm (11 augustus 1999).

46 De titel van deze oratie is gedeeltelijk ontleend aan de titel van een werkstuk van Annelies Jacobs en Anna Verhoeven. Zij onderzochten in 2004 onder mijn begeleiding de betekenis van muziek voor automobilisten. Hun ongepubliceerd verslag van dat onderzoek was getiteld "Weg van muziek: Privacy en de luxe van het luisteren in de auto." Ik dank hen voor hun toestemming om de eerste twee woorden van hun titel ook in de titel van de oratie op te nemen. 
